\title{
Training in Psychology and the Institutional Scientific Initiation Scholarship Program
}

\author{
Andressa Maia de Oliveira - Universidade Federal do Rio Grande do Norte, Natal, Brasil \\ Oswaldo Hajime Yamamoto - Universidade Federal do Rio Grande do Norte, Natal, Brasil
}

\begin{abstract}
This study has investigated how the Institutional Scientific Initiation Scholarship Program (PIBIC, in Portuguese), strategic initiative for research training at the undergraduate level, contributes to the formation of psychologists. Electronic questionnaires were sent to the PIBIC scholarship students of psychology in Brazil (622; 104 answered), containing questions about developed activities and tutoring. Scientific production was also investigated through their Lattes (curriculum vitae). Results show that: (1) students perform technical activities and reflective ones; (2) $50 \%$ execute a personal scientific project; and (3) $25 \%$ of the students have published scientific articles or book chapters, demonstrating that they are possibly excluded from this phase of the research process. However, the proximity with the advisor is related to the accomplishment of tasks, which contributes to a reflective training. Finally, it is emphasized the potential role for the undergraduate education to develop more critical psychologists able to propose contextualized practices.

Keywords: students, teaching, psychology; scientific activities
\end{abstract}

Formação em Psicologia e o Programa Institucional de Bolsas de Iniciação Científica

\begin{abstract}
Resumo
Este trabalho investigou como o Programa Institucional de Bolsas de Iniciação Científica (PIBIC), iniciativa estratégica para a formação em pesquisa na graduação, contribui para a formação dos psicólogos. Foram enviados questionários eletrônicos para todos os bolsistas alunos de Psicologia (622; 104 responderam) com questões sobre atividades e orientação. Investigou-se a produção científica por meio de consulta aos currículos Lattes. Dentre os resultados obtidos destacam-se: (1) os bolsistas executam desde atividades mais técnicas até as mais reflexivas; (2) metade deles desenvolve um projeto de pesquisa individual; (3) menos de $25 \%$ dos estudantes publicaram artigos ou capítulos de livros, demonstrando possível exclusão dessa fase. Contudo, a proximidade com o orientador relaciona-se à realização de tarefas que favorecem a formação crítico-reflexiva. Por fim, destaca-se o potencial do PIBIC para a formação de psicólogos mais críticos e capazes de propor inovações e práticas contextualizadas. Palavras-chave: estudantes, ensino, Psicologia, atividades científicas
\end{abstract}

Formación en Psicología y Programa Institucional de Becas de Iniciación Científica

\begin{abstract}
Resumen
Este trabajo analizó cómo el Programa Institucional de Becas de Iniciación Científica (PIBIC), contribuye en la formación de psicólogos, siendo ésta una iniciativa estratégica de investigación en la graduación. Se enviaron cuestionarios electrónicos para todos los alumnos becarios de Psicología (622; 104 respondieron) con preguntas sobre actividades y orientación. Se investigó la producción científica por medio de consulta a los currículos Lattes. Entre los resultados obtenidos se destacan: (1) Los becarios ejecutan desde las actividades más técnicas hasta las de mayor reflexión; (2) La mitad de ellos desarrollan un proyecto de investigación individual; (3) menos del 25\% de los estudiantes publicaron artículos o capítulos de libros, demostrando esto, una posible exclusión de esta fase. Sin embargo, la proximidad con el orientador se relaciona con la realización de tareas que favorecen la formación crítico-reflexiva. Finalmente, se destaca el potencial del PIBIC para la formación de psicólogos más críticos y capaces de proponer innovaciones y prácticas contextualizadas.

Palabras-clave: estudiantes; enseñanza; Psicología; actividades científicas.
\end{abstract}

The quality of psychology undergraduate education in Brazil has been discussed since its regulation. Classic studies have addressed issues such as: the dissatisfaction of professionals with content, especially in relation to the philosophical, methodological, and scientific foundations (Gomide, 1988); the opposition between science and practice, with courses that focus on theory and invest little in research, forming technicist professionals (Francisco \& Bastos, 2005); the relationship between poor training and a practice in disagreement with the socio-economic reality and the needs of the public (Bock, 1997); the booming number of private sector undergraduate courses in the field and its possible relation to the low quality of the courses (Yamamoto, Souza, Silva \& Zanelli, 2010); the perception of students on courses' infrastructure (library, laboratories, etc.) (Lima \& Pereira, 2011); the way the courses have implemented curriculum changes after the National Curricular Guidelines (DCN), and how they have responded to historical dilemmas on the basic training of psychologists (Seixas, 2014); among other aspects. 
In this context of structural criticism, scientific training is one aspect that has been touted as one of the main deficits in the students' formation (Ades, 1981; Bastos, Gondim, Souza e Souza, 2011; Cruces, 2008; Ferrarini \& Camargo, 2014; Francisco \& Bastos, 2005). A factor that is related to this deficit is the historical opposition between research and practice, which may be illustrated by the way disciplines were organized in the first psychology courses, structured around the minimum curriculum. The subjects were arranged so that the most basic were in the beginning of the course (research and experimentation) and the most practical were taught near the end of the course. Thus, students were presented with two distinct epistemological realities, as if there were a basic psychology, related to research, separate from applied psychology, linked to practice (Ades, 1981; Gomes, 2003).

Some data from two large studies help to illustrate this setting: the first, still in the 1980s, points out that research training was given essentially through the subject of Scientific Methodology and laboratory exercises in the subjects of Experimental Psychology and Statistics, and that in the survey "Who is the Brazilian psychologist?" only $5.1 \%$ of psychologists reported some involvement in research (Matos, 1988). More recently, Bastos et al. (2011) discussed the ENADE 2006 (National Exam for the Assessment of Student Performance) results, showing that the structural axes related to Historical and Epistemological Foundations and to Investigation and Measures (that includes scientific training) were those in which students obtained the lowest scores.

In a more recent research, Seixas (2014) investigated 40 Pedagogical Projects of Psychology Courses (PPCs) throughout Brazil. The results on scientific training showed that the academic-scientific contents were fragmented in various subjects and not concentrated in one subject; and that among the practical activities offered in the course subjects, those related to research appeared as some of the most cited in the courses summaries ("technical and scientific research production", for instance, is among the five most recurrent). However, Seixas (2014) explains that, despite the explicit concern with the integration of scientific research and the academic contents in the new PPCs, we cannot say that students have effectively participated in all research process, once in Brazil, few Higher Education Institutions (HEIs) actually invest in research.

In summary, literature indicates that graduation in psychology has a deficient training, focusing on theory and technique, and that it is unable to pass on to undergraduate students the basic knowledge for qualified practice and scientific investigation. This setting is worsen by the research training that is still deficient (sometimes even non-existent) and the gap between theory, practice, and knowledge production, which, despite the recent changes in the theoretical and philosophical discourses of the PPCs and the curricula implemented after the DCNs, still emerge as the main gaps between undergraduate school and practice. As a result, professionals with a bachelor's degree in psychology are underqualified and little prepared for the practice, especially in new contexts, when they end up by using classical instruments in most cases, without assessing suitability to the context (Bock, 1997; Botomé, 1988; Branco, 1998; Cruces, 2008; Ferrarini \& Camargo, 2014; Lisboa \& Barbosa, 2009; Martins, Matos \& Maciel, 2009).

Given this situation, some authors indicate that investment in research training would be beneficial both to increase the quality of training, and for the preparation of competent professionals, as a factor that would allow for the expansion of the professional field, knowledge production, and the construction of more critical practices (Bock, 1997; Calazans, 1999; Caniato, 2013; Ferrarini \& Camargo, 2014; Francisco \& Bastos, 2005; Maccariello, Novicki, \& Castro, 1999). In a classic text, Ades (1981) discusses the importance of research training for the graduate student in psychology, not from the perspective of a research career, but of a broad and complete professional training, whether academic or not. One of the advantages of such training includes the "path for the formation of a creative attitude of investigation and theorizing, valid both inside and outside the laboratory" (Ades, 1981, p.113), besides encouraging an attitude of curiosity and inquiry.

The author also believes that, one of the main results of the investment in research training is the critical positioning of the professional psychologist on the techniques and knowledge that he applies, questioning how they were developed and for what purpose, and whether, in fact, they apply to the context in which they are acting. Training in research would provide this ability in two ways: "showing how we don't know, showing how complicated it is to know anything" (Ades, 1981, p.116).

Among the ways of fostering undergraduate scientific training, the Institutional Scientific Initiation Scholarship Program (PIBIC) stands out. Offered by the National Council for Scientific and Technological 
Development (CNPq), it was created in 1989 and it is a research incentive program whose main objective is the scientific initiation of undergraduate students in all areas of knowledge, favoring the active participation in research projects with academic quality and adequate advising (Simão, 1996). Its objectives are to develop skills and competencies for scientific research in undergraduate students, thus contributing to the training of human resources for research; to bring undergraduate and graduate studies closer; to qualify students for postgraduate studies, contributing for a possible reduction in the time of completion of masters and doctoral degrees; and to reduce regional disparities regarding science development (Bridi, 2004).

The Bill approved by Decree n. 4728 of June 9, 2003, which established the general and specific rules for PIBIC scholarships and other types of quota scholarship schemes in the country, defines as an obligation of the fellows: "dedication to the activities planned for the project or work plan approved by $\mathrm{CNPq}$, for the duration of the scholarship" (National Council for Scientific and Technological Development [CNPq], 2003, Fellow Obligations, par. 1). The regulation is too vague, and thus, it leaves room for students to be used in tasks such as bureaucratic duties, for instance, or even tasks that go beyond the area of the research project, moving away from the more general objective of the program of "development of scientific thought and research initiation of undergraduate students" (CNPq, 2003, "PIBIC Purpose", par.1).

Bridi (2004) explains that PIBIC regulatory documents are restricted in what they refer to training, as they are limited to the training of the researcher for academic life. However, with the data obtained in his research, the author acknowledges that professors and fellows see this activity as a possibility to achieve an educational function that goes beyond the training of the specialized researcher, contributing thus to the intellectual, critical and ethical development of students, providing autonomy and creativity in the learning process. In this sense, the research practice takes on a pedagogical role with the possibility of development of various skills, including the knowledge on theories, methodologies and an investigative attitude that contributes to the formation of the scientific thinking during graduation (Bianchetti, Oliveira, Silva \& Turnes, 2012).

One of PIBIC requirements is that a research professor with academic and scientific experience guides the fellow student. The goal is that the student receives a direct monitoring of his activities, helping the professor in his project in exchange for the acquisition of scientific knowledge, learning about the whole process of research, from the writing of the project until the final written study, passing through bibliographic research, and data collection and analysis. In addition, there is also a kind of "initiation", since there is often not only an academic advising in the strict sense of formal knowledge, but also as a way to "stimulate productive researchers to engage undergraduate students in scientific, technological, professional, and artistic and cultural activities." (CNPq, 2013, Specific Objectives in relation to advisors, par.1). And also: "to provide the fellow, guided by a qualified researcher, with the knowledge of techniques and research methods, and to stimulate the development of scientific thinking and creativity, resulting from the conditions created by direct confrontation with the research problems" (CNPq, 2013, Specific Objectives in relation to fellows, par.1).

In general, literature points to the positive performance of PIBIC in the training of students. Massi and Queiroz (2010) led a comprehensive review and analyzed some studies conducted in Brazil on PIBIC, with results obtained by scientific initiation experiences in different courses (such as Mathematics, Education, Psychology, among others). The main results attributed to the participation of the student in Scientific Initiation (SI) go beyond the objectives set out formally, such as the development of different skills and the more effective preparation of students for academic, professional, and personal life. Thus, this enables a greater integration between theory and practice, developing critical thinking and an investigative attitude, contributing more broadly to the formation of critical professionals.

Given the positive results of PIBIC and the real possibility of improvement in the quality of graduate training, the objective of this study is to identify which features of PIBIC bring benefits to the training of psychologists.

\section{Method}

\section{Participants}

The subjects of this research were students of psychology, PIBIC/CNPq fellows in the area of psychology, who agreed to answer a questionnaire about their training.

Among the 104 respondents, 71.2\% were female and $28.8 \%$ male. In terms of age, $64.4 \%$ 
were between 21 and 23 years old, $21.2 \%$ from 24 to $26,6.7 \%$ were 30 or more, $5.8 \%$ were between 18 and 20 , and $1.9 \%$ between 27 and 29 . Regarding the legal and administrative nature of the higher education institutions (HEIs) in which they were enrolled, $66.3 \%$ were enrolled in public HEIs, $19.2 \%$ in private institutions and $14.4 \%$ in private confessional institutions. Regarding the shift in which they were enrolled, $51.9 \%$ were full-time students, $27.9 \%$ attended the morning or evening shift, $17.3 \%$ the evening shift, and $2.9 \%$ did not answer.

\section{Instrument}

The electronic questionnaire comprised questions intended to address the following issues:

- socio-demographic information - open questions;

- activities developed by the student - activities were listed and the students had to check whether they performed them or not and the degree of importance for their training (very high, high, indifferent, low, very low);

- advising - multiple-choice closed questions, on frequency of supervision, topics covered in the meetings, among others.

In addition, a parallel search at the Lattes $\mathrm{CNPq}$ site was carried out in order to map the academicscientific production of the fellows, aimed at finding information on presentation of papers in academic and scientific events and other forms of publication, such as articles and book chapters. We adopted this strategy, instead of including it as a section of the questionnaire, so as not increase the response time, which could decrease the number of respondents.

\section{Proceedings}

We conducted a data collection at the CNPq site to identify the names and electronic addresses of all fellows in the area of psychology. An electronic questionnaire was sent to the 622 registered fellows and the total number of respondents was 104 .

The electronic questionnaire was sent out along with a text explaining the research and a Free Consent Form, meeting the ethical requirements for the conduction of research in human beings. After a week, the percentage of return was of $10 \%$. The questionnaire was sent two more times, with an interval of 15 days, with a percentage of response of $16.7 \%$.

\section{Proceedings for data analysis}

Collected data were entered into a statistical software electronic database. The analyses were descriptive, presenting the percentage of respondents for different responses. The chi-square statistical test was used to analyze the relation between variables.

\section{Results and discussion}

The results were organized in three sections (1) Activities, (2) Advising and (3) Academic-scientific production. This division was used due to its frequency in the literature and because it showed relevant aspects for the understanding of the formation of the SI programs.

\section{Activities}

To better investigate this aspect, we performed an a posteriori classification of activities as "technical activities" and "reflective activities". Technical activities are those that are possibly related to repetitive tasks, often mechanic, not reflective. The following activities were included in this category: bibliographic search, data collection, entering information in a database, organization and tabulation of data, and activities of organization and maintenance. The reflective activities category refers to those activities that can enable the development of the critical and intellectual potential of the students, as the use of reflective and creative abilities are imperative for their development. This group includes the following activities: development of research project, data analysis, choice of instrument for data collection, development of an instrument, and reading/study.

Such division was based on previous studies (Bridi, 2004; Maldonado, 1998; Massi, 2008; Massi \& Queiroz, 2010) - some of qualitative nature, which described the fellows' tasks in detail - and it is an attempt to group the listed activities. The purpose of this classification was to better understand how the PIBIC experience could contribute to the formation of the psychology undergraduate student, besides trying to find which variables would possibly be related to a more complete integration in the academic-scientific activities. Table 1 presents the data on the activities conducted by students in their role as fellows.

Data showed in Table 1 indicates that psychology fellows do not participate in all activities of the research process. The bibliographic search was the activity cited by the highest number of fellows $(96.2 \%)$, followed by data analysis $(95.2 \%)$ and by 
study (92.3\%). Some studies (Caberlon, 2003, Maldonado, 1998, Fava-de-Moraes \& Fava, 2000) have already shown that the fellows' tasks are concentrated in activities such as literature review and data collection and tabulation, and that they are often excluded from activities more centered on the planning and finalization of the research, which are activities that would further stimulate their critical and creative potential, such as writing the theoretical referential and the systematization and assessment of data. Table 2 presents the frequency and percentage of students per quantity of reflective activities and quantity of technical activities developed.

Table 2 shows that there is a higher concentration of fellows that develop from four to five reflective activities $(65.4 \%)$, and that $78.8 \%$ of fellows perform from four to five technical activities. However, from the way data were organized, it is not possible to make further considerations, because if we consider the total number of activities developed, there is a higher concentration of fellows who perform between six and 10 activities $(92.2 \%)$, no student who performs only one, two or three activities, and only eight students who perform between four and five activities. Therefore, since more than $90 \%$ of participants reported conducting six or more activities, which extrapolates the maximum number of activities per category, it is clear that the two types of activities are present among fellows' responsibilities.

This setting is positive for the training of fellows, since the activities that potentially provide the criticalreflective development are essential for the education of future researchers. It is true that technical activities also have a role in the instruction of fellows, as part of a complete training process. However, once the fellow remains only in the level of technical activities, PIBIC will not be fulfilling its genuine role of scientific preparation (Caberlon, 2003). Literature points that (Bridi, 2004; Leite, 1996) for a complete formation, fellows must perform tasks from both natures; however, they should not be burdened by the more technical activities.

\section{Advising}

Advising is one of the key points for a good progress of PIBIC. Therefore, to understand whether it happens in a way to provide a better benefit from the program, we investigated its functioning by means of three pieces of information: the first about who actually supervises the fellow; the second is the frequency of meetings; and the third is related to the theme of these supervisions.

According to collected data, we verified that it is the professor who holds the quota of scholarships the one who directly monitors the work of more than half

Table 1

Activities conducted

\begin{tabular}{lc}
\hline Activities & Performed \\
\hline Technical activities & \\
Bibliographic search & 96.2 \\
Organization / Tabulation of data & 90.4 \\
Data collection & 89.4 \\
Organization of the research group & 74.0 \\
Entering information on database & 54.8 \\
\hline Reflective activities & \\
Data analysis & 95.2 \\
Study & 92.3 \\
Research project design & 77.9 \\
Instrument selection & 62.5 \\
Instrument development & 51.9 \\
\hline Other activities & 13.1 \\
Ex.: participation in scientific events; monitoring other students, etc. & \\
\hline
\end{tabular}

Note. All figures refer to a percentage of students who reported performing a given activity, $\mathrm{N}=104$. 
Table 2

Amount of performed activities

\begin{tabular}{lcccc}
\hline \multirow{2}{*}{ Quantity of activities } & \multicolumn{2}{c}{ Reflective Activities } & \multicolumn{2}{c}{ Technical activities } \\
\cline { 2 - 5 } & $\mathrm{n}$ & $\%$ & $\mathrm{n}$ & 0 \\
\hline 0 & 1 & 1 & 1 & 1 \\
1 & 1 & 1 & 8 & 7.7 \\
2 & 16 & 15.4 & 13 & 12.5 \\
3 & 18 & 17.3 & 45 & 4.3 \\
4 & 32 & 30.8 & 37 & 35.6 \\
5 & 36 & 34.6 & 104 & 100 \\
\hline
\end{tabular}

of the PIBIC students in Psychology (65.4\%). However, it is important to discuss the other $34.6 \%$ who reported that other people have supervised their training, such as the research group as a whole (15.4\%), a post-graduate student from the research group $(8.7 \%)$, and others $(10.5 \%)$.

The $\mathrm{CNPq}$ regulations about the SI program establishes that it is the obligation of the researcher who holds the quota of scholarships to follow the process of development of the fellow students, being directly responsible for his training, as a novice researcher. "The advisor is forbidden to pass the supervision of his fellow to others. In case of an eventual impediment of the advisor, the fellow shall return to the coordination of scientific research of the institution" (CNPq, 2003). It is extremely important that the fellow contacts other researchers, and even shares knowledge and experiences with other SIs. The experience of participating in a research group is one of the richest aspects of SI, once it allows for contact with other studies, with researchers at different levels of scientific training, and thus, growth is more complete and diversified (Simão, 1996).

Although the selection process of advisors only through the professors' CV is not a guarantee of quality advising, it is a way of ensuring that the student will be linked to a researcher who already has an entry in the field. Thus, it is worrying to think that one third of the fellows in the area of psychology does not have a direct follow-up by the research professor, because the quality control of this supervision escapes from the development agency. In addition, the dialogic relationship advisor-advisee is crucial for the learning based on action-reflection (Simão, 1996) once it is a direct relationship (student-centered model), which enables the exchange of experiences and values (Tenório \& Beraldi, 2010). It is still a way to mediate the entry of the SI student in the selected academic world, being indispensable for the structuring of academic relations and for the student to feel part of this group (Oliveira, Araújo \& Bianchetti, 2014).

It should also be questioned why these professors do not devote time to the supervision of their advisees, since they offer this activity and make this commitment with the program. The overload work to which professors are subjected to might be the reason. Studies such as those by Marcuschi (1996) and Rodrigues (1996) indicate that the work at the Higher Education Institutions demands much more from professors than the hours spent in the classroom and that they do not value the work of advising in SI. The demand for higher productivity, the various posts held (both at the university, and at agencies such as the Coordination for the Improvement of Higher Education Personnel - CAPES, Research Support Foundations - FAPs, CNPq, and scientific societies), as well as other assignments, may be factors that end up by leaving the professor overloaded, and he ends up getting careless with some of his many tasks, delegating some of his functions to third parties (such as post-graduate students). The fact that SI is not considered among the professors' duties put them as a way of work overload. This situation does not justify the absence of the advisor in his designations, but we cannot simply disregard the context in which the process takes place. Furthermore, this is not a factor that indicates, for instance, precariousness in the program, or that it does not have a good standard of quality, but it is an indicative that it is not working as planned. 
Regarding the frequency of advising sessions, $31.7 \%$ of respondents reported having, on average, one meeting per week, $28.8 \%$, more than one meeting a week, $19.2 \%$, one meeting every 15 days, $9.6 \%$, once a month; and $10.6 \%$ once every three months or less. Leite (1996) states that advisee-advisor relationship can range from an emphasis on full autonomy to a closer monitoring. It can be assumed that either autonomy or close monitoring are not only related to the quantity of meetings, but also with how the orientation process takes place as a whole, regarding, for instance, the work style, ranging from only the delegation of tasks to the individual development of a research. However, based on the above information, we can have an indication that the advisors are present in the fellow's academic routine, as $80 \%$ report meeting their advisor once or more every 15 days, which can be considered a high frequency.

The two previously exposed variables are directly related to the quality of advising that the fellow receives, so it is possible that students who are directly supervised by their advisors also have more frequent orientation meetings. In order to investigate whether there is such a relationship in the data collected, we used the chi-square $(\chi 2)$ statistical test to analyze the variables "Frequency of supervisions" and "Advising". However, to meet the statistical prerogatives of this test, it was necessary to group the categories of the contingent variables ("Once or more every 15 days" / "Less that once every 15 days" x "Professor advisor" / "Other than the advisor").

Among the students who are guided directly by the professor who holds the quota of scholarships, $91.2 \%$ is supervised one or more times every 15 days and $8.8 \%$, less than once every 15 days. Among those who are supervised by third parties, $58.3 \%$ are supervised one or more times every 15 days and $41.7 \%$, less than once every 15 days. The chi-square test indicated the existence of a significant relationship between the variables "Frequency of supervisions" and "Monitoring", $\chi^{2}(1, \mathrm{~N}=104)=15.75, p<0.001$. Therefore, it is possible to infer that the students who are followed directly by the professor advisor have more frequent orientation meetings.

Regarding the main topic of supervisions, more than half the fellows $(52.9 \%)$ reported that the main topic in the meetings was the research project and its operational issues. Other agendas such as theoretical discussion on the research theme and guidelines for the study account for $29.8 \%$. Supervision regarding the writing process totaled $12.5 \%$ and $4.8 \%$ did not answer.
By investigating the expectations and frustrations of SI fellows, Bridi (2004) found that in relation to advising $67 \%$ expected to have a "direct personal supervision that would help in the construction and development of the research project" and among the $53 \%$ who mentioned some frustration with the program, the most cited $(17 \%)$ was related to the lack of a greater contact with the advisor. Fellows believe that these advisors did not fully fulfill their role due to lack of time and excess of activities. The absence of the advisor in this process can be critical, not only for a research training deficient in the technical and theoretical aspects, but also in the sense of discouraging the student's affection for the scientific activity.

In order to investigate which conditions foster the further development of activities regarded as critical-reflexive, as these are the activities that actually provide the actual training of the researcher, we proposed the joint analysis of information on the amount of reflective activities with other conditions of the fellow's training. Among the factors that can lead to a more comprehensive instruction, there are the number of meetings for supervision and whether the professor who holds the quota of scholarships is actually the one that follows the fellow. In order to identify whether there is a significant relationship between the amount of reflective activities and a higher frequency of supervisions, we conducted a chi-square statistical test $(\chi 2)$.

Such as in the previous analysis, it was necessary to combine some categories of response. Once most participants reported performing more than four activities, we chose two categories: "less than four reflective activities" and "four or more reflective activities".

Among students who perform less than four reflective activities, $36.1 \%$ have less than one supervision meeting every 15 days and $63.9 \%$ have supervision meetings once or more every 15 days. Among those conducting four or more reflective activities, $11.8 \%$ are counseled less than once every 15 days and $79.8 \%$ have meetings every 15 days or longer. The chi-square statistical test $(\chi 2)$ showed that there is a significant relation between the researched variables, $\chi^{2}(1, \mathrm{~N}=104)=$ $8.65, p<0.01$. Therefore, we may say that students who have a higher frequency of meetings perform more activities that contribute for their education and critical development.

The other relationship analyzed was the one between the amount of reflective activities and who is responsible for supervision. Among those students who perform less than four reflective activities, $47.2 \%$ 
are followed by others than the advisor, and $52.8 \%$ by the professor holder of the scholarship quota. Among those who perform more than four reflective activities, $27.9 \%$ are advised by third parties and $72.1 \%$ by the professor who holds the quota of scholarships. The statistical test showed that there is a relationship, $\chi 2(1$, $\mathrm{N}=104)=3.86, p<0.05$, between the variables, i.e., fellows guided directly by the professor who holds the quota of scholarships perform more activities directly related to the critical development.

The relations described above direct a reflection: that the advisor plays an essential role for the development of the tasks that require intellectual, critical, and reflective effort. One aspect that can elucidate this issue is the case of IS fellows who rarely or never interact directly with the professor (who should be the advisor), being relegated to assist other participants in the laboratory/research group, for instance, post-graduate students (masters or doctorate). This type of relationship can turn the fellow into an executor of technical activities without educational sense, becoming only "cheap labor force", which promotes "a typical exploitation of bureaucratic assistance" (Fava-de-Moraes \& Fava, 2000, p. 76).

\section{Academic and Scientific Production}

The academic-scientific production stands as an aspect of unquestionable importance in the attempt to compose the portrait of the formation of the Scientific Initiation fellow. The dissemination of research results is the last stage of the process of scientific knowledge production and the student should not be excluded from it (Massi, 2008).

The information described below was collected from the résumés of fellows registered in the CNPq Lattes Platform (it is required that all fellows be registered in the platform and keep their information updated). There are several forms of dissemination of scientific knowledge; here we will consider articles published in scientific journals, book chapters, and articles (complete and abstracts) published in annals of conferences. Table 3 shows the percentage of fellows who published each product type (articles, book chapters and papers in events) and the amount of production.

According to Table 3, the percentage of fellows who have some kind of publication is $67 \%$, i.e., 70 out of the 104 surveyed. From data presented, it is clear that among the respondent fellows, 24\% published articles, $10.6 \%$ published book chapters, and 64.4\% published studies in events. The amount of material produced by fellow ranges from one to 10 , and there is a greater concentration in the range of one to two published studies $(28.6 \%)$.

Given that it is part of the obligations of the fellows to present their studies at least once a year in SI congresses organized by the HEIs to which their grants are linked, to better understand the phenomenon we will exclude the category "studies published in annals of events" from further analyzes.

In publications recorded in their Lattes CV (curriculum vitae), as a single author or first author, there are more fellows figuring as co-authors than as authors: $14.4 \%$ reported having at least one publication as an author and $23.1 \%$ have at least one publication as coauthor. However, the difference found is not as great as expected. Since the fellows are still being trained as researchers, often assisting studies from other academic levels, they could more often feature as a co-author rather than as the author of the studies they publish. It is also remarkable the considerable number of fellows who are first authors of publications, even still attending undergraduate school- beginning their training in research.

The low number of fellows who publish the results of their projects in article format (less than $30 \%)$ is also noteworthy, since scientific writing is

Table 3

Percentage of fellows who published and amount of publications

\begin{tabular}{lcccccccc}
\hline \multirow{2}{*}{ Items published } & \multirow{2}{*}{ \% of fellows } & \multicolumn{7}{c}{ Amount of publications $^{\mathrm{a}}$} \\
\cline { 3 - 8 } & & 1 & 2 & 3 & 4 & 5 & 6 or + & 0 \\
\hline Articles & 23.1 & 11.5 & 4.8 & 1.9 & 1.0 & 1.0 & 2.9 & 76.9 \\
Book chapters & 10.6 & 6.7 & 1.9 & 1.0 & 0.0 & 0.0 & 0.0 & 90.4 \\
Papers in events & 64.4 & 8.7 & 8.7 & 2.9 & 4.8 & 1.9 & 37.5 & 35.6 \\
\hline
\end{tabular}

a. Amount of publications (in percentage) $=$ Amount of authorships + co-authorship of each respondent student 
central to the formation of the researcher, not only for the obvious exercise of critical reflection, but also because the practice of this activity may be related to the development of other aspects such as autonomy, critical thinking, understanding, and mastery of scientific content (Massi, 2008). The collected information is in line with the data already submitted by Caberlon (2003) and the discussion of Maldonado (1998) on the difficulties of integrating the students in all stages of research, especially in those requiring more creative and intellectual resourcefulness.

\section{Final Considerations}

The positive aspects of PIBIC, as well as other SI programs, have long been celebrated in the literature. And that is not without reason. SI has shown effective to the student's inclusion in the world of science and the way it is developed provides an involvement that often exceeds the technical and rational level. It is common for students and mentors to have a positive emotional relationship with the program and its results. The studies to date on the SI program show its promising results and its development potential.

In relation to the activities developed, data suggests that fellows in psychology tend to perform activities of various kinds, from the most technical to the most critical, half of them developing even an individual research project. This is an important indicative for the positive evaluation of the program's contribution, since it is essential that the student participate in the whole process of scientific work. Participation in all activities does not guarantee the development of an investigative and critical attitude, but it certainly provides the foundations for it. Thus "improvement will come indirectly, without the predictability or stereotyping that may apply in other aspects of training" (Ades, 1981, p.134). However, what we observe from the collected data is that few fellows publish articles and book chapters, which can reveal their exclusion from such an important phase of science, the writing and dissemination of results, which would serve as a basis for the development of various skills.

Furthermore, the advisor-fellow relationship is shown to be essential to understand the training process. The possibility of developing projects with experienced researchers provides a broad understanding of the scientific work. As already pointed out by Ades (1981), the orientation relationship enables the acquisition of the unofficial scientific making, such as the choice of certain paths during the search, the ability to relate empirical findings and theory, the ability to relate basic knowledge with practice, among others.

The data presented here revealed that there is a significant relationship between the person who actually advises and the other variables concerning the quality of training; for instance, with the frequency of meetings for orientation and the amount of activities more directly related with critical and reflective development. In addition, the data show that the fellows that are advised more often in person perform more activities that contribute to their training and critical development. However, the issue of advising is shown as a problem to be investigated in greater depth, since the data gathered in this research indicate that a considerable number of students are not being followed directly by their advisors (34.6\%), which can mean great loss for these students.

The information outlined above points to the great potential that PIBIC can have for the training of the psychologist as a more critical professional, able to question his knowledge and to propose innovations and contextualized practices, so that the future professional is not restricted to the application of techniques learned in textbooks. In addition, programs such as PIBIC, which have been demonstrated as important for the education of the student, give visibility to the disqualified training that most of the students (not fellows) receive, as they show that, a more qualified training is indeed possible. In this sense, the results also warn that the teaching conditions, in general, should be enhanced (and not only the creation of programs that reach few, important as they are).

Finally, we suggest further research from another perspective other than self-report, to investigate what are the activities developed by fellows in the program and how those can contribute to the future professional of psychology. This would decrease the possible bias regarding self-assessment research, in which participants tend to respond affirmatively to the questions in order to demonstrate a more positive assessment.

\section{References}

Ades, C. (1981). Treino em pesquisa, treino em compreensão. Psicologia: Ciência $e$ Profissão, 1(1), 107-140. Recuperado de http:// pepsic.bvsalud.org/scielo.php?pid $=$ S1414-98931981000100005\&script $=$ sci_arttext 
Bastos, A. V. B., Gondim, S. M. G., Souza, J. A. J., \& Souza, M. P. R. (2011). A formação básica e profissional do psicólogo: uma análise do desempenho das IES no ENADE 2006. Avaliação Psicológica, 10(3), 313-347.

Bianchetti, L., Oliveira, A, Silva, E. L., \& Turnes, L. (2012). A iniciação à pesquisa no Brasil: políticas de formação de jovens pesquisadores. Educação (Santa Maria), 37(3), 569-584.

Bock, A. M. B. (1997). Formação do psicólogo: um debate a partir do significado do fenômeno psicológico. Psicologia: Ciência e Profissão, 17(2), 37-42. Recuperado de http://www.scielo.br/pdf/pcp/ v17n2/06.pdf

Botomé, S. P. (1988). Em busca de perspectivas para a Psicologia como área de atuação e como campo profissional. In Conselho Federal de Psicologia (Org.), Quem é o psicólogo brasileiro? (pp. 273-297). São Paulo: Edicon.

Branco, M. T. (1998). Que profissional queremos formar? Psicologia: Ciência e Profissão, 18(3), 28-35. doi: http:// dx.doi.org/10.1590/S1414-98931998000300005

Bridi, J. C. (2004). A Iniciação Científica na formação do universitário (Dissertação de mestrado). Universidade Estadual de Campinas, Campinas. Recuperado de http://www.bdae.org.br/dspace/ handle/123456789/1205

Caberlon, V. I. (2003). Pesquisa e graduação na FURG: em busca de compreensões sob distintos horizontes (Tese de doutorado). Universidade Federal do Rio Grande do Sul, Porto Alegre.

Calazans, J. A. (Org.). (1999). Iniciação científica: construindo o pensamento crítico. São Paulo: Cortez.

Caniato, A. (2013). A Formação de Psicólogas e Psicólogos: respondendo às demandas da sociedade brasileira. Texto elaborado a partir da oficina Formação de Psicólogos organizada pelo CFP. Brasília: CFP Grupo de Trabalho sobre Formação.

Conselho Nacional de Desenvolvimento Científico e Tecnológico (2013). Normas gerais e específicas para bolsas por quota no País. Recuperado de http:// www.cnpq.br/view/-/journal_content/56_ INSTANCE_OoED/10157/100352

Cruces,A.V.(2008). Apesquisanaformaçãodepsicólogos brasileiros e suas políticas públicas. Boletim Academia Paulista de Psicologia, 2(8), 240-255. Recuperado de http:/ / pepsic.bvsalud.org/scielo.php?pid=S1415-711X2008000200012\&script=sci_arttext

Fava-de-Moraes, F., \& Fava, M. A. (2000). A iniciação científica: muitas vantagens e poucos riscos. São Paulo em Perspectiva, 14(1), 73-77. doi: http://dx.doi. org/10.1590/S0102-88392000000100008

Ferrarini, N. L., \& Camargo, D. (2014). O professor de Psicologia diante da multiplicidade e diversidade teórica da Psicologia: lugar de incertezas e de desafios. Psicologia: Ensino \& Formação, 5(1), 32-49.

Francisco, A. L., \& Bastos, A. V. B. (2005). Conhecimento, formação e prática: o necessário caminho da integração. In Conselho Federal de Psicologia (Org.), Psicólogo brasileiro: construção de novos espaços. $2^{\mathrm{a}}$ Ed. (pp. 71-88). Campinas: Alínea.

Gomes, W. B. (2003). Pesquisa e prática em Psicologia no Brasil. In O. H. Yamamoto \& V. V. Gouveia. (Orgs.), Construindo a Psicologia brasileira: desafios da ciência e da prática psicológica (pp. 23-59). São Paulo: Casa do Psicólogo.

Gomide, P. I. C. (1988). A formação acadêmica: onde residem suas deficiências. In Conselho Federal de Psicologia (Org.), Quem é o psicólogo Brasileiro? (pp. 69-85). São Paulo: Edicon.

Leite, S. A. S. (1996). Desafios para a pesquisa sobre iniciação científica em Psicologia. In E. M. Bomfim (Org.), Formações em Psicologia: pós-graduação e graduação (pp. 89-96). Belo Horizonte: ANPEPP/ UFMG.

Lima, M., \& Pereira, M. A. T. (2011). Percepção dos estudantes sobre infraestrutura dos cursos de psicologia: considerações a partir do ENADE-2006. Avaliação Psicológica, 10(3), 349-363.

Lisboa, F. S., \& Barbosa, A. J. G. (2009). Formação em Psicologia no Brasil: um Perfil dos Cursos de Graduação. Psicologia Ciência e Profissão, 29(4), 718-737.

Maccariello, M. C., Novicki, V., \& Castro, E. M. (1999). Ação pedagógica na Iniciação Científica. In J. C. Calazans (Org.), Iniciação científica: construindo o pensamento crítico (pp. 79-115). São Paulo: Cortez.

Maldonado, L. A. (1998). Iniciação científica na graduação em Nutrição: autonomia do pensar e do faz̧er na visão dos pesquisadores/orientadores (Dissertação de mestrado). Universidade do Estado do Rio de Janeiro, Rio de Janeiro. 
Marcuschi, L. A. (1996). Avaliação do Programa Institucional de Bolsas de Iniciação Científica (PIBIC) do $\mathrm{CNPq}$ e proposta de ação (Relatório Final). Recife: Universidade Federal de Pernambuco.

Martins, K. P. H., Matos, T. G. R. \& Maciel, R. H. M. O. (2009). Formação em Psicologia e as novas demandas sociais: relato dos egressos da Universidade de Fortaleza. Revista Mal-Estar e Subjetividade, 9(3), 1023-1042.

Massi, L. (2008). Contribuições da iniciação científica na apropriação da linguagem científica por alunos de graduação em Quimica (Dissertação de mestrado). Universidade de São Paulo, São Carlos. Recuperado de http:// www.teses.usp.br/teses/disponiveis/75/75132/ tde-18042008-112848/pt-br.php

Massi, L., \& Queiroz, S. L. (2010). Iniciação científica: funcionamento e contribuições. Campinas: Átomo.

Matos, M. A. (1988). Produção e formação científica em Psicologia. In Conselho Federal de Psicologia (Org.), Quem é o psicólogo brasileiro? (pp. 100-122). São Paulo: Edicon.

Oliveira, A., Araújo, E. R., \& Bianchetti, L. (2014). A fase da iniciação científica e a ruptura no tempo - destino: Esboço de uma problemática sobre a preparação e expectativas de carreira na investigação científica. Tempos Sociais e o Mundo Contemporâneo - As crises, As Fases e as Ruturas, 336-351.
Rodrigues, M. M. P. (1996). Iniciação científica: o que dizem as agências de fomento? In E. M. Bomfim (Org.), Formações em Psicologia: pós-graduação e graduação (pp. 89-96). Belo Horizonte: ANPEPP/ UFMG.

Seixas, P. S. (2014). A Formação Graduada em Psicologia no Brasil: reflexão sobre os principais dilemas em um contexto Pós-DCN. Tese de doutorado. Universidade Federal do Rio Grande do Norte, Natal. Recuperado de: http://repositorio.ufrn.br/jspui/ handle/123456789/17401

Simão, L. M. (1996). A Iniciação Científica enquanto processo de construção de conhecimento: um enfoque para reflexão. In E. M. Bomfim (Org.), Formações em Psicologia: pós-graduação e graduação (pp. 89-96). Belo Horizonte: ANPEPP/UFMG.

Tenório, M. do P., \& Beraldi, G. (2010). Iniciação científica no Brasil e nos cursos de Medicina. Revista Associação Médica Brasileira, 56(4), 375-93.

Yamamoto, O. H.; Souza, J. A. J.; Silva, N., \& Zanelli, J. C. (2010). A formação básica, pós-graduada e complementar do psicólogo no Brasil. In A. V. B. Bastos \& S. M. G. Gondim (Orgs.), O trabalho do Psicólogo no Brasil (pp. 45- 65). Porto Alegre: Artmed.

Recebido em: 31/07/2015

Reformulado em: 31/01/2016; 25/02/2016

Aceito em: 26/02/2016 
Sobre os autores:

Andressa Maia de Oliveira é psicóloga da Secretaria Municipal de Trabalho e Assistência Social do Município do Natal - RN, membro do Grupo de Pesquisas Marxismo \& Educação e mestre em Psicologia pela Universidade Federal do Rio Grande do Norte.

E-mail: andressamaiaoliveira@gmail.com

Oswaldo Hajime Yamamoto é professor titular do Departamento de Psicologia da Universidade Federal do Rio Grande do Norte, doutor em Educação pela Universidade de São Paulo e Pesquisador 1B do CNPq e coordenador do Grupo de Pesquisas Marxismo \& Educação.

E-mail: oswaldo.yamamoto@gmail.com

Contato com os autores:

Campus Universitário UFRN, Lagoa Nova

Natal-RN, Brasil

CEP: 59078-970 